Думенко М. П., к.військ.н.

Головне управління Генерального штабу Збройних Сил України

\title{
Методика формування резерву кандидатів до призначення на визначену вакантну посаду
}

Резюме. В статті розглянуто питання укомплектування вакантних посад підготовленим особовим складом. При цьому запропонована методика розроблена 3 використанням методів факторного та кластерного аналізу.

Ключові слова: укомплектованість підготовленим особовим складом; кадрові органи; рейтинг; рейтинговий список; список кандидатів до призначення на визначену посаду.

Постановка проблеми. Створення сучасної системи кадрового менеджменту у Збройних Силах України передбачені положеннями наступних керівних документів: Стратегічним оборонним бюлетенем України, Планом дій щодо впровадження оборонної

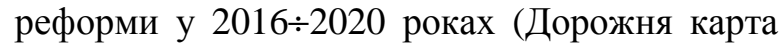
оборонної реформи) - оперативна ціль 5.4. "Створення сучасної системи кадрового менеджменту", Концепцією військової кадрової політики у Збройних Силах України на період до 2020 року та Дорожньою картою iï реалізації [1-4].

Зазначені керівні документи визначають поетапне створення у Збройних Силах України сучасної системи кадрового менеджменту, яка забезпечить до кінця 2020 року впровадження раціонального співвідношення категорій особового складу, створення ефективної системи управління кар'єрою військовослужбовців, забезпечення прозорої та доброчесної системи добору, розстановки та призначення особового складу на посади, в основі якої на першому місці не кількісні, а якісні показники.

Під час формування резерву формується рейтинговий список. Рейтинговий список список військовослужбовців до призначення на визначену вакантну посаду, у якому місце (номер за порядком) кожного військовослужбовця визначається кількісною величиною його рейтингу.

Узагальнення переліку вакантних посад та складання рейтингових списків здійснюється фахівцями кадрових центрів видів Збройних Сил України, на яких покладені завдання щодо управління кар'єрою військовослужбовців, іiї супроводження, персоналізація у роботі 3 ними та комплектування визначених вакантних посад військовослужбовцями.

Визначення рейтингу відібраних кандидатів та формування рейтингових списків покладається на відповідну комісію кадрових органів 3 відбору кандидатів до призначення на посади (далі - Комісія) за відповідними військово-обліковими спеціальностями та номенклатурою.

Рейтинговий список $\epsilon$ підставою для підготовки пропозицій Командувачу виду Збройних Сил України щодо прийняття кадрових рішень по кожній вакантній посаді окремо.

При роботі комісії виникає проблема людського фактору, тобто має місце вплив суб'єктивної думки членів Комісії щодо рейтингу кандидатів на вакантну посаду.

Аналіз останніх досліджень i публікацій. Для зменшення впливу суб'єктивного фактору застосовують відомі математичні методи, зокрема таксономії, факторного та кластерного аналізу, які досить детально розроблені та апробовані у різних галузях.

Суть факторного аналізу полягає в тому, що групу скорельованих ознак можна пояснити та описати невеликою кількістю прихованих (латентних) факторів, які безпосередньо не спостерігаються, але розкривають значення ознак цієї групи. Наприклад, за такими ознаками, як "кількість прочитаних книг", “кількість книг у домашній бібліотеці", “кількість відвідувань театрів і музеїв", приховано фактор, який можна було б назвати "рівень культурного розвитку особистості". Факторний аналіз дає змогу виявити ці латентні фактори, описати залежність між ними та первинними ознаками, обчислити значення всіх побудованих таким чином факторів для кожного об'єкта. В результаті виникає можливість без значних втрат інформації перейти від аналізу великої кількості первинних ознак до аналізу порівняно невеликої кількості факторів.

Алгоритми кластерного аналізу дають змогу поділити сукупність об'єктів на однорідні 
за певним формальним критерієм подібності групи (кластери). Основною властивістю цих груп є те, що об'єкти, які належать одному кластеру, подібніші між собою, ніж об'єкти 3 різних кластерів. Таку класифікацію можна виконувати одночасно за досить великою кількістю ознак. Наприклад, відомо чимало статистичних показників, які характеризують рівень соціально-економічного розвитку адміністративних районів країни: кількість населення, кількість безробітних, протяжність шосейних доріг, кількість квадратних метрів житла на одну людину тощо. Для організації опитування необхідно згрупувати райони у більші утворення (регіони), але варто зробити це так, щоб у кожному такому регіоні були райони, близькі за своїм соціальноекономічним розвитком. Це дасть змогу вибрати в такому регіоні один типовий район i результати опитування в ньому узагальнити щодо всього регіону. Таке групування може бути ефективно проведене методом кластерного аналізу, оскільки у даному разі враховується та узагальнюється велика кількість показників [5-8].

Метою статті $\epsilon$ висвітлення підходу до формування резерву кандидатів для призначення на визначену вакантну посаду 3 використанням методів таксономії, факторного і кластерного аналізу, що надасть змогу зменшити вплив суб'єктивного фактору на формування рейтингового списку.

Виклад основного матеріалу дослідження. Відбір та визначення рейтингу військовослужбовців здійснюється 3 метою підвищення якості укомплектування вакантних посад найбільш підготовленими фахівцями, здатними виконувати увесь спектр поставлених завдань на відповідних посадах, у тому числі в умовах ведення бойових дій.

Сам рейтинг являє собою індивідуальний кількісний або порядковий показник успішності, затребуваності та відповідності вимогам паспорту військової посади, який відображає позицію військовослужбовця по відношенню до інших військовослужбовців за підсумками незалежного, деталізованого оцінювання усього спектру результатів його службової діяльності за визначеною кількістю критеріїв (показників).

Процедура визначення рейтингу військовослужбовців складається 3 декількох послідовних етапів, що забезпечують комплексне рейтингове дослідження. Комплексне рейтингове дослідження включає в себе процедури:
- відбору військовослужбовців на

визначену посаду;

- складання відповідних списків;

- уточнення рейтингу кандидатів для просування по службі на засіданні комісії 3 відбору кандидатів до призначення на посади.

Для вирішення питання укомплектованості підготовленим особовим складом пропонується покласти основи факторного та кластерного аналізу.

Для реалізації зазначеного використовується математичний апарат, завдяки якому методика визначення рейтингу військовослужбовців претендує на зведення до мінімуму впливу протекціонізму та людського фактору.

В основу математичного апарату покладено, зазначений вище, відомий у науці метод кластерного аналізу багато параметричних об'єктів із визначенням таксономічного показника їх важливості.

Під багато параметричним об'єктом мається на увазі військовослужбовець із притаманним йому певним набором ознак, за якими і здійснюється оцінювання.

Слід зазначити, що запропонована методика за своїми загальними підходами не відрізняється від інших в цьому напрямку. Проте основною різницею запропонованого підходу $\epsilon$ застосування методу кластерного аналізу.

Як і у відомих методиках, основними етапами є процедури:

- стандартизації параметрів;

- визначення коефіцієнтів ієрархії;

- та побудова рейтингу.

Процедура стандартизації полягає у вирівнянні оціночної шкали параметрів, яка визначається визначеною кількістю балів для кожної ознаки.

Це дуже складна й відповідальна процедура для командирів, які мають оцінювати мужність, професійні знання, етику поведінки тощо цифрами за визначеною балами шкалою.

Визначення коефіцієнтів ієрархії, тобто співвідношення між собою професійних якостей, мужності, знання іноземної мови тощо, вимагатиме від експертів компетентності у цій справі. Та й визначення самих експертів, які, як мінімум, повинні мати відповідний досвід, зазнає значних труднощів та не вирішує проблему впливу людського фактору.

Сам же рейтинг будується за принципом простого арифметичного складання оціночних балів за кожним з параметрів (рис.1). 


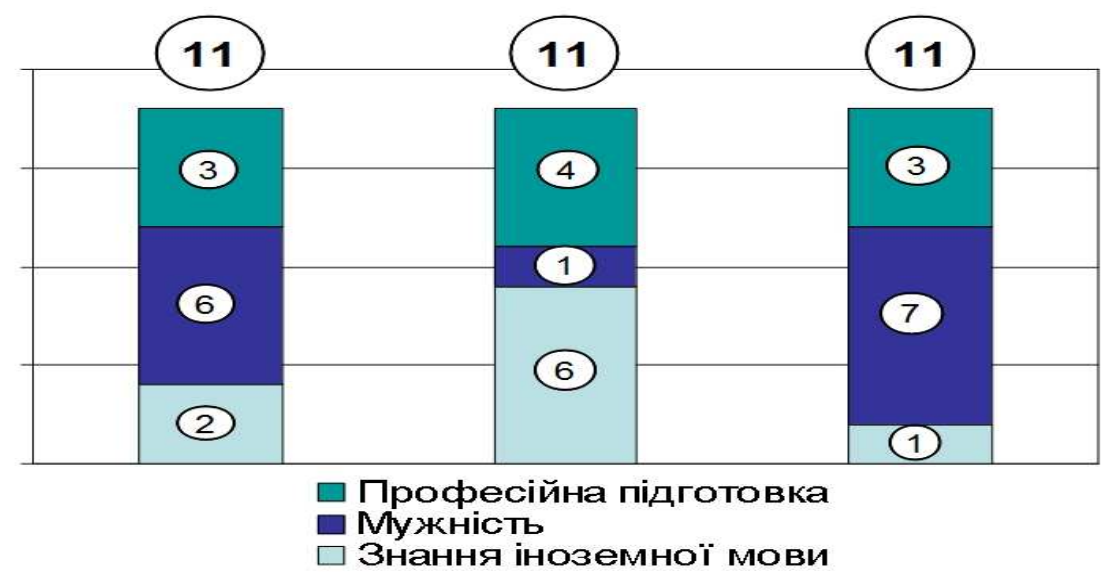

Рис. 1. Оцінка та упорядкування за важливістю багатометричних об'сктів

(військовослужбовців).

Саме тут i виникає суперечливе запитання, - якщо загальна кількість балів однакова? 3 одного боку - i рейтинг однаковий. 3 іншого - як бути, коли у одного військовослужбовця оцінка мужності значна, а знання іноземної мови невелика, а у іншого - навпаки.
Одним із шляхів вирішення цього питання $\epsilon$ визначення оціночною комісією одного 3 параметрів, або їх набору, які будуть вирішальними. Це логічно i зрозуміло. Але коли кількість параметрів значна - це $\epsilon$ складною задачею для членів комісії, які $\epsilon$ людьми та мають власне право на помилку (рис. 2).

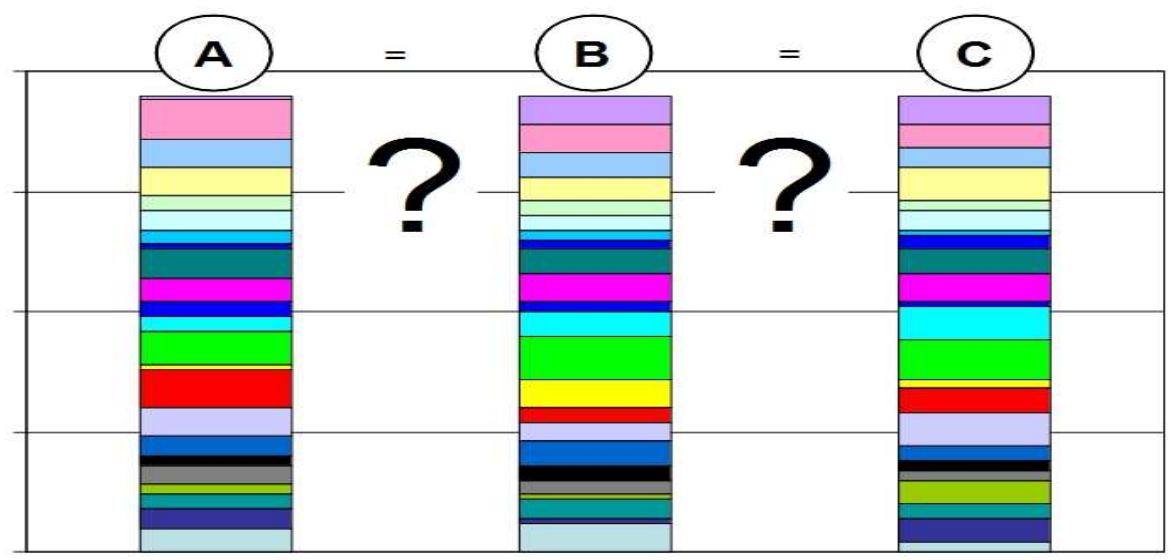

Рис. 2. Методика оцінки та упорядкування за важливістю багатометричних об'сктів (військовослужбовців) за значною кількістю критерії.

Метод кластерного аналізу передбачає розподіл загальної характеристики всіх військовослужбовців на, так звані, кластери, області однакової фізичної природи. У кластері формується еталонна величина, відносно якої визначається положення кожного об'єкта оцінювання за ознакою, яка формує даний кластер (рис. 3).

По-іншому, це означає, що оцінка військовослужбовця, наприклад його мужність, здійснюється не за кількістю балів, а за величиною відхилення даної оцінки від еталону, наприклад середнього значення оцінок за мужність всіх військовослужбовців.

Стандартизація передбачає перехід до виміру параметрів об’єктів у відносних одиницях.

Методикою також передбачено питання визначення коефіцієнтів ієрархії. 3 метою усунення людського фактору запропоновано для визначення коефіцієнтів вагомості характеристик військовослужбовців, замість 
методу експертних оцінок, яким передбачено залучення досвідчених фахівців із своїм людським фактором, використовувати метод коефіцієнтів ієрархій, який визначає вагомість тієї чи іншої характеристики математично.
Зазначений метод оснований на пошуку відстаней між характеристиками. Якщо відстані менше, - характеристика міцніше. А це означає, що вона краще, та коефіцієнт ієрархії більший [6].

\section{Професійна підготовка}

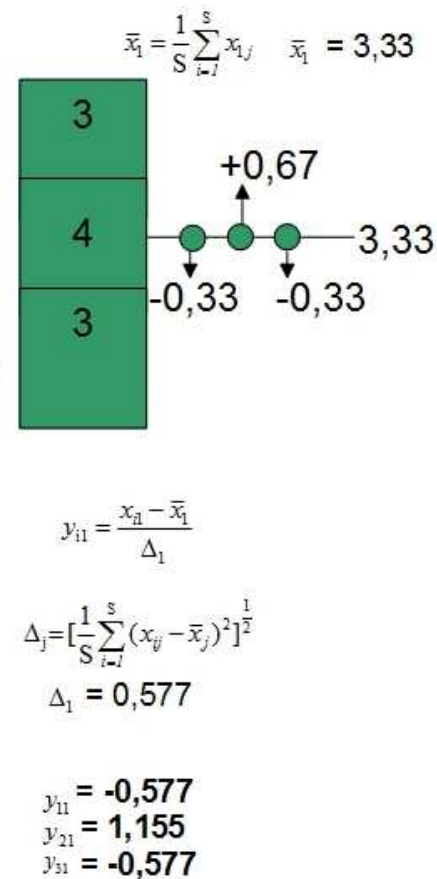

Мужність

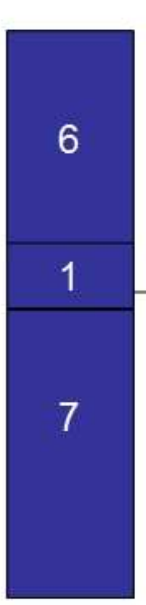

$\bar{x}_{2}=\frac{1}{\mathrm{~S}} \sum_{i=1}^{\mathrm{S}} x_{2 j} \quad \bar{x}_{2}=4,67$

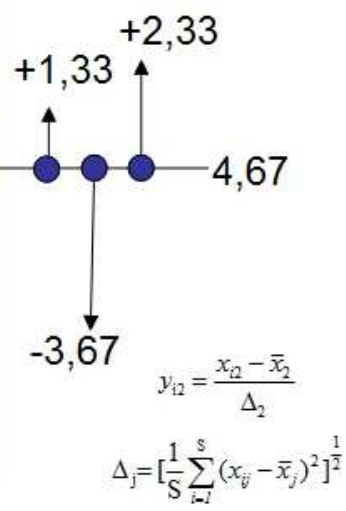

$\Delta_{2}=3,215$

$$
\begin{aligned}
& y_{12}=0,415 \\
& y_{22}=-1,141 \\
& y_{32}=0,726
\end{aligned}
$$

\section{Знання іноземної мови}

$$
\bar{x}_{1}=\frac{1}{S} \sum_{i=1}^{S} x_{1 j} \quad \bar{x}_{1}=3
$$

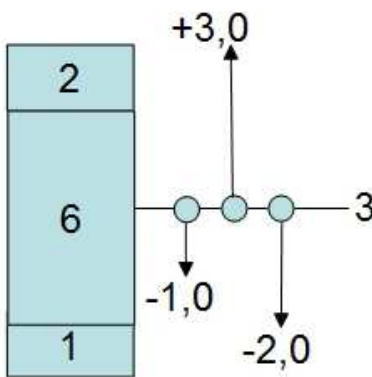

$$
\begin{gathered}
y_{i 1}=\frac{x_{i 1}-\bar{x}_{1}}{\Delta_{1}} \\
\Delta_{\mathrm{j}}=\left[\frac{1}{\mathrm{~S}} \sum_{i=1}^{\mathrm{S}}\left(x_{i j}-\bar{x}_{j}\right)^{2}\right]^{\frac{1}{2}}
\end{gathered}
$$$$
\Delta_{3}=2,646
$$

$$
\begin{aligned}
& y_{13}=-\mathbf{0 , 3 7 8} \\
& y_{23}=\mathbf{1}, 134 \\
& y_{33}=-0,756
\end{aligned}
$$

\section{Рис. 3. Стандартизація критеріїв}

Фізично це означає таке. Льотчиками, або танкістами можуть бути лише льотчики або танкісти, або ті, хто має відповідну підготовку та рівень знань. Стрілком 3 великою вірогідністю також можуть бути льотчики та танкісти. Тому у стрілка відстані більше, а зв'язки слабше (рис.4).

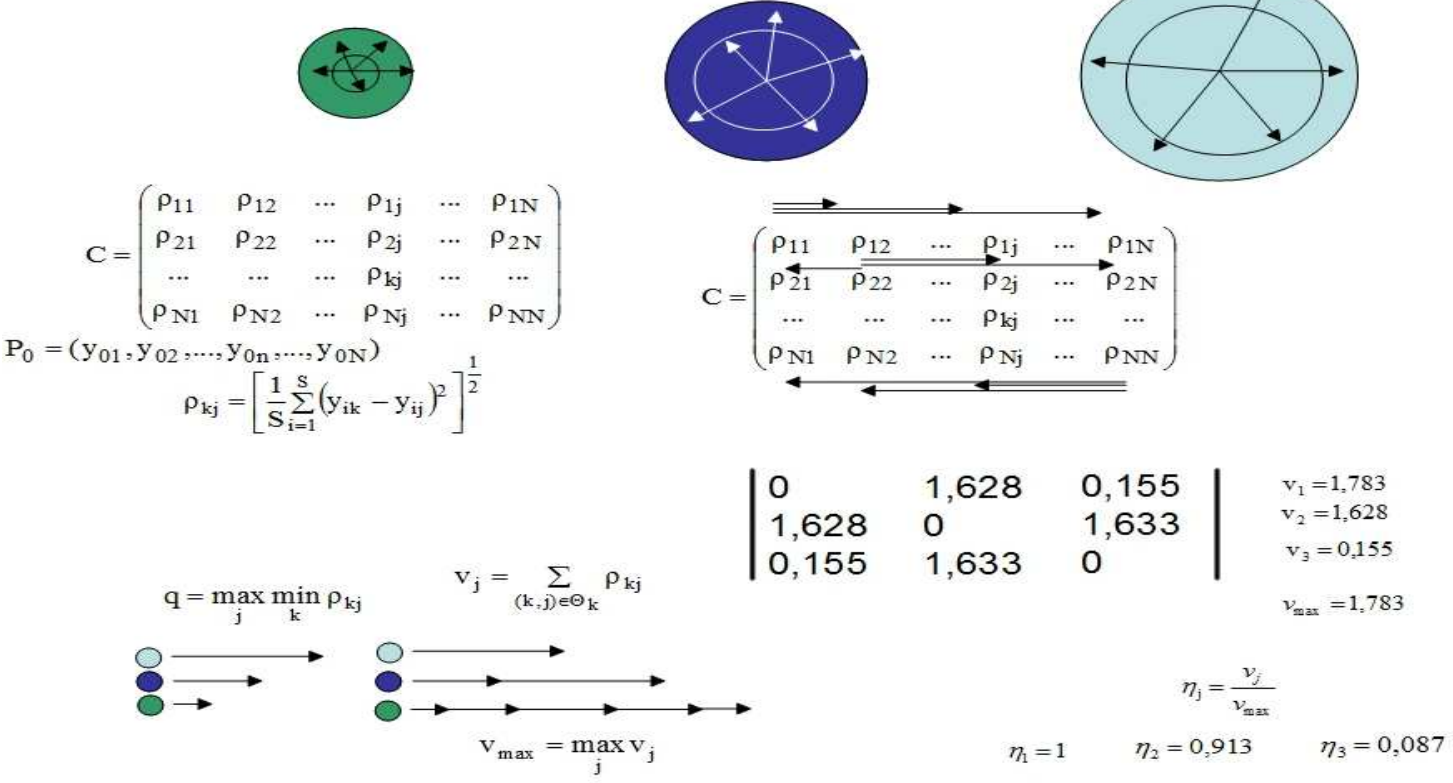

Рис. 4. Коефіцієнти ієрархії 
Останнім кроком $є$ визначення рейтингу. Рейтинг визначається за принципом, хто ближче до еталону, - той краще (рис. 5).

Складною та відповідальною процедурою є визначення балу за відповідною характеристикою. Це питання вирішується за допомогою методу тестових оцінок, математичний апарат якого побудований за рекомендаціями Артюшина-Полуйка та широко використовується у Національному університеті оборони України [9].

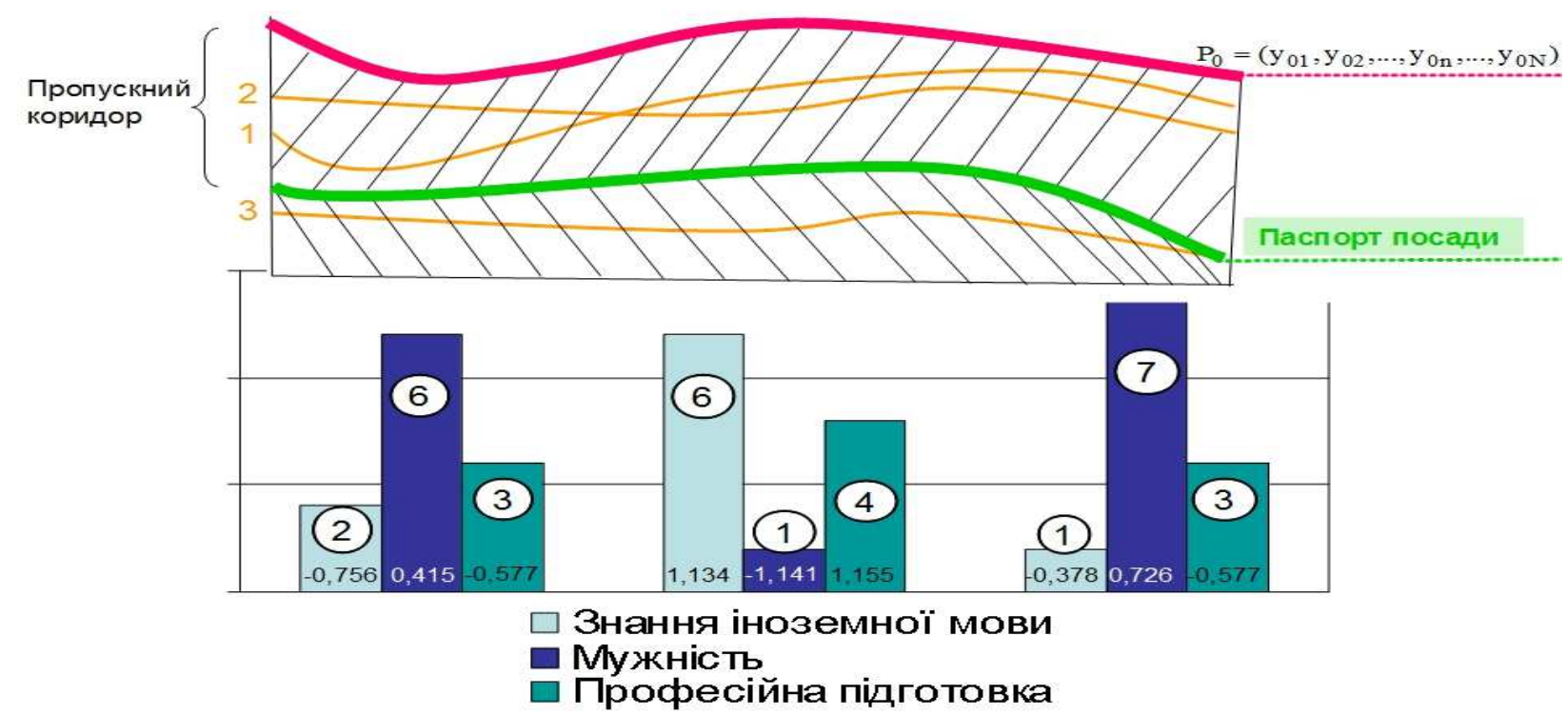

Рис. 5. Оцінка та упорядкування за важливістю багатометричних об'єктів (військовослужбовців).

Суть методу така. Формуються питання та варіанти відповідей до них. Кожен варіант відповідей має свій бал за вірністю. Оцінка вірної відповіді максимальна. Загальна сума балів вірних відповідей дорівнює 100.

Оціночний бал того, хто атестується дорівнюється сумі балів за варіантами його відповідей за умов:

$$
\begin{aligned}
& \text { - } 2 \text { бали - 0-59\% знань; } \\
& \text { - } 3 \text { - 60-74\%; } 4 \text { - 75-86; } \\
& \text { - } 5 \text { - 90-100\%. }
\end{aligned}
$$

Висновок. Аналіз даних передбачає використання великої кількості взаємопов'язаних ознак, що в свою чергу потребує значних обчислень. Для ефективного застосування запропонованої методики необхідно автоматизувати процеси визначення рейтингу військовослужбовців, для чого потрібне спеціальне програмне забезпечення.

Перспективою використання зазначеного підходу $\epsilon$ формування у Кадровому центрі Збройних Сил України центрального серверу обробки даних, які мають використовуватися у видах Збройних Сил України, оперативних командуваннях, науково-дослідних установах та вищих військових навчальних закладів тощо. За необхідністю, пошук претендентів на посаду, паспорт якої закладається у центральному сервері, здійснюється менеджером Кадрового центру.
За бажанням рейтинг може будуватися у будь-якій частині, та кожен із військовослужбовців має можливість доступу до нього для планування подальших особистих дій. Це означатиме, що кожен із військовослужбовців має можливість прогнозувати свою кар'єру. Визначившись із власним місцем у рейтингу, кожен може прийняти самостійно рішення щодо підвищення рівня професійних знань та умінь, рівня фізичної підготовки тощо, для чого потрібно, певним чином, коригувати план індивідуальної підготовки.

Подальші дослідження доцільно спрямувати на подальше удосконалення науковометодичного апарату функціонування кадрових органів щодо виконання визначених завдань.

\section{СПИСОК ВИКОРИСТАНОЇ ЛІТЕРАТУРИ}

1. Про Стратегію сталого розвитку "Україна - 2020" // Указ Президента України від 12 січня 2015 року № 5/2015№ 5/2015.

2. Стратегічний оборонний бюлетень України // Указ Президента України №240/2016 від 6 червня 2016 року "Про рішення Ради національної безпеки i оборони України від 20 травня 2016 року "Про Стратегічний оборонний бюлетень України".

3. План дій щодо впровадження оборонної реформи у 2016 - 2020 роках (Дорожня карта оборонної реформи) // Затверджено Міністром оборони України 15.08.2016.

4. Указ Президента України від 26.05.2015 № 287/2015 "Про рішення Ради національної безпеки і оборони 
України від 06.05.2015 року "Про Стратегію національної безпеки України”.

5. Плюта В. Сравнительный многомерный анализ в экономических исследования: Методы таксономии и факторного анализа / Пер. с пол. В. В. Иванова; науч. ред. В. М. Жуковской. - М., 1980.

6. Плюта В. А. Сравнительный многомерный анализ в экономических исследованиях. Методы таксономии и факторного анализа . - М .,1980.-80 c.Joresrog K.G. Statistical estimation in factor analysis. A new technique and its foundation. Inaugural dissertation: Uppsala, $145 \mathrm{p}$.

7. Дюран Б., Оделл К. Кластерный анализ. /Под ред. А. Я. Боярского. Пер. с англ. - М.: Статистика, 1977. $128 \mathrm{c}$.

8. Мандель И. Д. Кластерный анализ. - М.: Финансы и статистика, 1988. - 176 с.

9. Методичний посібник з контролю засвоєння змісту навчання слухачами Національної академії оборони України // Національна академія оборони України, 2003 .

Стаття надійшла до редакційної колегії 27.12.2018

\section{Думенко Н. П., к.воен.н.}

Главное управление персоналом Генерального штаба Вооружённых Сил Украины

Методика формирования резерва кандидатов для назначения на определенную вакантную должность

Резюме. В статье рассмотрены вопросы укомплектования вакантных должностей подготовленным личным составом. При этом предложенная методика разработана с использованием методов факторного и кластерного анализа.

Ключевые слова: укомплектованность подготовленным личным составом; кадровые органы; рейтинг; рейтинговый список; список кандидатов для назначения на определенную должность.

\section{N. Dumenko, PhD (Military)}

General Staff Directorate of the General Staff of the Armed Forces of Ukraine

Methods of forming a reserve of candidates for appointment to a specific vacant position

Resume. The article deals with the issues of staffing vacant positions with trained personnel. At the same time, the proposed methodology was developed using the methods of factor and cluster analysis.

Keywords: staffing by trained personnel; personnel bodies; rating; rating list; list of candidates for appointment to a certain position. 